\title{
Um passo à frente
}

\section{One step forward}

A trajetória de um empreendimento, vista apenas na perspectiva temporal, nem sempre reflete a sua real evolução dado que fatos significativos e experiências relevantes podem ocorrer em períodos relativamente curtos. Esta afirmação óbvia é aqui lembrada porque se aplica como uma luva à ainda breve história da Revista Brasileira de Saúde Materno Infantil.

Realmente, ao comemorar dois anos de existência, é por demais oportuno fazermos um balanço do que a Revista já caminhou e, ao mesmo tempo, vislumbrarmos o longo trajeto que ainda resta percorrer.

Neste itinerário é mister reconhecer, em primeiro lugar, que o periódico não nasceu do nada. Digamos que aflorou em um terreno fértil, pois, na verdade foi criado sobre a égide da sua precursora, a Revista do IMIP, a qual, sem lacuna no seu calendário editorial, foi editada com regularidade pelo Instituto Materno Infantil de Pernambuco durante 14 anos. É um produto natural de sua antecessora, porém numa dimensão incomensuravelmente maior. Tratando-se de atender à crescente demanda de publicações especificamente na área da saúde materno-infantil, ela se apresenta como pioneira entre os periódicos brasileiros e mesmo Latino- americanos.

Ao lado desta origem a RBSMI dificilmente teria "vingado" não fosse o suporte do Instituto Materno Infantil de Pernambuco, instituição de ensino e pesquisa com mais de 40 anos e casa editora de longa experiência em publicações de boletins informativos, pautas de serviço e livros didáticos constituindo as Séries - Publicações Científicas e Publicações Técnicas, as quais são reconhecidas em muitos centros universitários e acadêmicos brasileiros interessados nos aspectos clínicos, epidemiológicos e sócio-culturais da saúde da mulher e da criança.

Evidentemente a Revista contou com a fundamental participação do seu corpo editorial que não mediu esforços no sentido de conferir-lhe uma fisionomia científica de excelência, o que lhe tem permitido conquistar, pouco a pouco, um lugar entre as publicações congêneres.

Podemos dizer que neste curto período de um biênio, objetivos fundamentais para um periódico que pretende veicular informação técnico-científica de alto nível, têm sido alcançados. Assim é auspicioso dizer que a Revista foi indexada originalmente ao LILACS e incluída, já no início deste ano, às bases de dados ligadas à CAB Internacional, a saber, CAB Abstracts, CAB Health, Sociological Abstracts, Social Services Abstracts Worldwide Political Science Abstracts, Linguistics \& Language Behavior Abstracts. Recentemente foi também indexada à base Nutrition Abstracts and Reviews (é interessante notar que cerca de 30\% dos artigos já publicados se referem a estudos sobre temas nutricionais, especialmente em crianças e gestantes).

Conseqüentemente a sua visibilidade é agora muito maior do que o foi nos primeiros meses de publicação. Isto permite, sem dúvida, a sua inserção no grupo de periódicos de qualidade, mas ao mesmo tempo exige um empenho redobrado do seu corpo editorial e dos consultores ad hoc na seleção de artigos de nível condizentes com as exigências da comunidade de leitores a que se destina.

Esta experiência, positiva até o momento, nos tem dado grande esperança no futuro, permitindo-nos tomar decisões fundamentais para a consolidação da Revista. Sem entrar em pormenores, podemos confirmar a decisão de aumentar a sua frequiência, alterando a periodicidade que, já no próximo ano, passará a ser trimestral (março, junho, setembro e dezembro) e não mais quadrimestral. Fatores como o aumento de articulistas, a necessidade de inclusão em outras bases de dados e a busca de uma maior divulgação dos temas na área maternoinfantil foram determinantes nesta decisão, que acreditamos ser extremamente importante para o futuro da Revista. De fato verificamos hoje, que os seus colaboradores procedem das mais diferentes regiões geográficas.

Por tudo isto entendemos que o êxito até aqui alcançado nos permite chegar ao final do ano e concluir o segundo volume com bastante otimismo, tendo em mente, entretanto, que este sucesso deve ser visto como apenas um passo à frente no nosso trabalho.

José Eulálio Cabral Filho

Revista Brasileira de Saúde Materno Infantil / Brazilian Journal of Mother and Child Health Editor Associado. 